The following advertisements are from MRS members seeking employment in materials research and development.

\section{Prospective Employers-}

To correspond confidentially with the applicant, REPLY TO THE APPROPRIATE BOX NUMBER, AS FOLLOWS:

Box No.

c/o MRS Bulletin

Materials Research Society

9800 McKnight Road

Pittsburgh, PA 15237

Postdoc in materials science and engineering seeks industrial/academic research position. PhD (1992) in solid-state physics. Expertise in ion implantation, synthesis and characterization of SIMOX structures. Background in electronic materials processing. Instrumentation: TEM, SEM, SIMS XPS, Raman, RBS/Channeling, and $\mathrm{C} / \mathrm{V}$ measurements.

Employers-Please reply to Box XVIII, No. 1001.

PhD in solid-state physics, to be completed in November 1993. Experienced in measuring GaAs-\{Ga, Al)As heterostructures and $\mathrm{Er}$ implanted in $\mathrm{Si}$ with luminescence, ellipsometry, and other optical techniques. My address is: V. Bellani, Bellani Vittorio Dipartimento di Fisica, Via Bassi 6, I-27100 Pavia (Italy).

Employers-Please reply to Box XVIII, No. 1005.
Materials processing researcher seeks position in industrial/academic R\&D process engineering \& manufacturing. PhD in ME, specialized in materials science. Six years experience in thin-film coating and with vacuum roll/web coating equipment for electrical/electronic components, connectors, semiconductors. Five years industrial experience. Background in tribological analysis, autoCAD, modeling and simulation; also SEM, TEM, XRF, $x$-ray diffractometry. U.S. patent holder.

Employers-Please reply to Box XVIII, No. 1004.

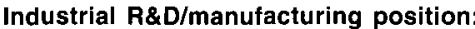
PhD in ceramic science. Research experience in processing and characterization of ultrafine powders and films. Skilled in chemical powder processing and spray pyrolysis. Industrial experience in refractory manufacturing and development. Adept at electron microscopy, $x$-ray diffraction, thermal analysis, and particle-size, size distribution, and surface area measurement. Excellent communication and interpersonal skills.

Employers-Please reply to Box XVIII, No. 1002.

Skilled PhD materials scientist with extensive experience in thin-film growth, characterization, and surface science. Background includes MBE of metals oxides, semiconductors; electron spectroscopy (XPS, AES), diffraction (RHEED LEED), and imaging (HRTEM); and all aspects of semiconductor processing. Excellent organizational and communication abilities. Seeking position in an innovative development environment

Employers-Please reply to Box XVIII, No. 1003.

\title{
MRS 1993 FALL MEETING
}

\section{SYMPOSIUM Ca: INTERFACE CONTROL OF ELECTRICAL, CHEMICAL, AND MEGHANICAL PROPERTIES}

In a special session on Thursday, December 2, T. Seidel, SEMATECH, will describe SEMATECH's road map; T. Ohmi, Tohoku University, will give a Japanese view of materials issues in semiconductor technology.

\section{COMING IN NOVEMBER}

Guest Editor Willard H. Sutton, United Technologies Research Center, will focus on Microwave Processing of Materials. Articles will include:

\section{Computer Modeling and} Numerical Simulation of Microwave Heating Systems, by Magdy F. Iskander, University of Utah.

Recent Developments in the Microwave Processing of Polymers, by David A. Lewis and Jane M. Shaw, IBM.

Recent Developments in the Microwave Processing of Ceramics, by David E. Clark, D.C. Folz, R.L. Schulz, Z. Fathi, and A.D. Cozzi; University of Florida.

Recent Developments in Microwave Joining, by Richard Silberglitt, FM Technologies; Iftikhar Ahmad, Technology Assessment \& Transfer, Inc.; W. Murray Black, George Mason University; and Joel D. Katz, Los Alamos National Laboratory.

\section{Microwave Processing of Metallorganics to Form Powders, Compacts, and} Functional Gradient Materials, by Monika A. Willert-Porada, University of Dortmund, Germany.

\section{Gyrotron Processing of}

Materials, by Boris E. Paton and

Vladislav E. Sklyarevich, E.O.

Paton Electric Welding Institute,

Ukraine; and Marko M.G.

Slusarczuk, USP Holdings.

Ad closings for the MRS Bulletin:

November 1 for December '93 issue, December 3 for January '94 issue.

To place your ad, call Mary E. Kaufold at (412) 367-3036 today! 